\title{
PROBLEMATIKA PENDIDIK SOSIOLOGI ANTROPOLOGI DI MASYARAKAT MULTIKULTURAL
}

\author{
Oleh: \\ Zaini Rohmad ${ }^{1}$
}

\begin{abstract}
Abstrak
Masyarakat multikultural adalah suatu masyarakat yang beragam kumunitas budaya dengan segala kelebihannya, dan kekurangannya tentang konsepsi mengenai dunia, suatu sistem arti, nilai, bentuk organisasi sosial, sejarah, adat serta kebiasaan. Berdasarkan hal di atas, kajian ini berdasarkan konsepsi teoritis mengenai problematika pendidik sosiologi antropologi di masyarakat multicultural. Minimal ada empat hal yang dialami pendidik di masyarakat multikultural, yakni: (1) tuntutan penyetaraan pelayanan dalam menyeleksi dan mengintegrasikan isi (content selection and integration); (2) masalah "proses mengkonstruksikan pengetahuan" (the knowledge construction process); (3) menguragi prasangka (prejudice reduction)? (4) sejauhmana guru mampu memilih aspek dan unsur budaya yang relevan dengan isi dan topik mata pelajaran, sehingga peserta didik menuntut penyetaraan pendidikan (equity of education). Berdasarkan uraian di atas, pendidikan harus memenuhi kriteria ilmiah (scienteific methods), dengan lebih mengedepankan penalaran induktif (inductive reasoning) dibandingkan dengan penalaran deduktif (deductive reasoning) dengan pendekatan kolaburatif dan kontekstual.
\end{abstract}

Kata Kunci: soiologi antropologi, permasalahan pendidikan, multikuturalisme, masyarakat

${ }_{1}$ Staf Pengajar di Pendidikan Sosiologi Antrapologi FKIP, dan S2 dan S3 di Pascasarjana, Universtas Sebelas Maret, Surakarta. 


\section{A. Pendahuluan}

Sebagaimana diketahui, bahwa masyarakat merupakan suatu jaringan hubunganhubungan antar entitas-entitas. Masyarakat adalah sebuah komunitas yang interdependen (saling tergantung satu sama lain). Pada umumnya, istilah masyarakat digunakan untuk mengacu sekelompok orang yang hidup bersama dalam satu komunitas yang teratur.Dapat dikatakan sebagai sebuah masyarakat apabila memiliki pemikiran, perasaan, serta sistem/aturan yang sama. Dengan kesamaan-kesamaan tersebut, manusia kemudian berinteraksi sesama mereka berdasarkan kemaslahatan. Proses yang demikian, masyarakat terbentuk.

Sedangkan Masyarakat Multikultural adalah suatu masyarakat yang hidup dalam suatu tempat dengan beberapa kebudayaan yang berbeda. Masyarakat multikultural biasanya menganut paham multikulturalisme, yaitu anggapan bahwa setiap budaya memiliki kedudukan yang sama atau sederajat dan memiliki kelebihannya masing-masing. Dengan faham ini seorang pendidik harus memahami berbagai corak budaya yang dianut oleh masyarakatnya, termasuk peserta didik yang sedang belajar di pendidikan formal.

Menurut Azra (Rohmad: 2017), Masyarakat multikultural adalah suatu masyarakat yang terdiri dari beberapa macam kumunitas budaya dengan segala kelebihannya, dengan sedikit perbedaan konsepsi mengenai dunia, suatu sistem arti, nilai, bentuk organisasi sosial, sejarah, adat serta kebiasaan ("A Multicultural society, then is one that includes several cultural communities with their overlapping but none the less distinc conception of the world, system of (meaning, values, forms of social organizations, historis, customs and practices)”). Jadi, masyarakat multikultural merupakan masyarakat yang menganut multikulturalisme, yaitu paham yang beranggapan bahwa berbagai budaya yang berbeda memiliki kedudukan yang sederajat.

Sedang tipe-tipe masyarakat multikultural adalah: (a). kompetisi seimbang: kelompok-kelompok yang ada mempunyai kekuasaan yang seimbang; (b). mayoritas dominan: kelompok terbesar mendominasi, contoh : Indonesia, umat Islam mayoritas dan memegang kekuasaan; (c). minoritas dominan: kelompok kecil yang mendominasi; (d). fragmentasi: masyarakat terdiri dari banyak kelompok yang kecil, tidak ada yang mendominasi.

Sedangkan ciri-ciri masyarakat multikultural adalah: (1) Segmentasi (terbagi) ke dalam kelompok-kelompok; (2) Kurang mengembangkan konsensus (kesepakatan bersama); (3) Sering mengalami konflik; (4) Integrasi sosial atas paksaan; dan (5) Dominasi (penguasaan) suatu kelompok atas kelompok lain. 
Sedangkan dalam UU No 20 tahun 2003 tentang Sistem Pendidikan Nasional menghendaki bahwa pendidikan diselenggarakan secara demokratis, berkeadilan serta tidak diskriminatif serta menjunjung tinggi HAM, nilai, religi, kultural, dan keberagaman suku bangsa, dan sebagai satu kesatuan yang sistemik dengan sistem terbuka dan multi makna. Berkaitan dengan hal tersebut, tujuan utama dari pendidikan adalah untuk menanamkan sikap simpati, respek, apresiasi, dan empati terhadap budaya yang berbeda dan etnis yang berbeda. Bagaimana bila terjadi perubahan dalam budaya nasional, kalaupun budaya daerah tergusur, tidak perlu risau selama nilai-nilai yang unggul diterima dan berkembang dalam masyarakat lokal.Dengan kata lain, budaya yang berdasarkan pada nilai-nilai 'kebenaran yang parsial atau marjinal' tidak dapat bertahan dalam jangka waktu yang lama atau permanen. Dengan cara demikian, seluruh nilai budaya yang ada dapat dijadikan sumber kekuatan dan ketahanan masyarakat dalam membangun dirinya, serta masyarakat berbudaya sebagai cita-cita bersama diniscayakan dapat terwujud.

Berdasarkan kondisi faktual di masyarakat dan tujuan utama sistem pendidikan nasional, pendidik mendapat amanah yang cukup berat dalam menata dan menanamkan nilai dan norma kepada masyarakat, khususnya kepada peserta didik.
Misalnya dalam proses mengkonstruksikan pengetahuan (the knowledge construction process); menyeleksi dan mengintegrasikan isi (content selection and integration) mata pelajaran; mengurangi prasangka (prejudice reduction); dan menyesetaraan pendidikan (equity paedagogy). Tugas pendidik, khususnya guru tidak mudah untuk menjalankan pekerjaannya. Barangkali tidak cukup dengan wacana SNGP(Standar Nasional Guru Profesional), dan Guru Profesional-yang terdiri dari (a) Profesi spiritual; (b)Profesi Paedagogy; (c) Profesi Profesional;dan (d) Profesi Sosial.

\section{B. Problema yang dihadaipi Pendidik Terhadap Peserta Didik}

Problema atau masalah adalah kesenjangan antara yang ada dengan yang seharusnya ada (das sain dengan dos sollen). Kesenjangan antara keadaan yang ada dengan keadaan yang seharusnya ada ini yang harus segera dipecahkan bersama agar tidak muncul masalah yang lebih rumit dan kompleks. Walau kita ketahui bahwa pendidikan merupakan investasi jangka panjang, sehingga perlu pemikiran yang lebih matang dan terencana.

Sebagaimana kita singgung di atas, problema yang dihadapi pendidik kepada peserta didik cukup komplek dan rumit, serta memerlukan ketekunan dan ketelitian oleh pelakunya, yakni pendidik atau guru. 
Tampaknya Menteri Pendidikan dan Kebudayaan, Prof. Dr. H. Muhadjir Effendy menyadari hal ini, sehingga seorang guru harus tinggal di sekolahan selama delapan jam per hari, guna mempersiapkan materi yang akan diajarkan atau yang akan sharingkan kepada peserta didik, agar tidak terjadi hal-hal yang tidak kita inginkan.

Bila kita amati, banyak sikap, keterampilan dan pengetahuan pendidik yang belum mencerminkan budayanya sendiri. Setiap hari kita dapat melihat dan mendengar berita dari lingkungan kita, baik melalui realita maupun melalui berita-berita, baik melalui berita di surat kabar, majalah mapun berita elektronik seperti TV, yang menunjukkan bahwa guru kurang mengenal budayanya sendiri, budaya lokal maupun budaya peserta didik; atau guru kurang menguasai garis besar struktur dan budaya etnis peserta didiknya, terutama dalam konteks mata pelajaran yang akan diajarkannya;

Masalah ini muncul apabila pendidik atau guru terlalu banyak memakai budaya etnis atau kelompok tertentu dan (secara tidak sadar) menafikan budaya kelompok lain. Untuk mempersiapkan atau memilih unsur budaya membutuhkan waktu, tenaga dan referensi dari berbagai sumber dan pustaka, mencari tahu dari tokoh sehingga guru dapat melaksanakan kesetaraan pedagogi. Pendidik harus memiliki "khasanah budaya" mengenai berbagai unsur budaya dalam tema tertentu, termasuk Tionghoa dan yang lainnya.
Bagaimana agar peserta didik yang belum mengenal budaya yang dijadikan media pembelajaran menjadi tidak berprasangka bahwa pendidik atau guru cenderung mengutamakan unsur budaya kelompok tertentu. Dalam perlakuan ini muncul masalah kesetaraan status budaya peserta didik yang budayanya jarang dijadikan media pembelajaran. Bagaimana pendidik atau guru dapat mengintegrasikan budaya lokal dalam mata pelajaran yang diajarkan, sehingga pembelajaran yang dilaksanakan lebih bermakna (meaningfull learning) bagi peserta didik. Bagaimana agar guru dapat mengusahakan "kerjasama" (cooperation) dan pengertian bahwa strategi pemakaian budaya tertentu bukan merupakan "kompetisi," melainkan sebuah kebersamaan.

Ditambah lagi, pandangan umum, tentang rendahnya kemampuan pendidik atau guru dalam mempersiapkan peralatan yang dapat merangsang minat, ingatan, dan pengenalan kembali peserta didik terhadap khasanah budaya masing-masing. Lebih-lebih di masyarakat multikultural seperti di Indonesia ini, dengan keberagamaan budaya indonesia dapat menimbulkan masalah dalam proses pembelajaran. Pendidik atau guru seharusnya dapat menggunakan frameof reference dari budaya tertentu dan mengembangkannya dalam perspektif ilmiah yang kini dikenal dengan pendekatan saintifik.

Secara garis besar, permasalahan yang sering diderita oleh pendidik atau guru 
pendidikan sosiologi antropologi, secara garis besarnya sebagai berikut:

1. Mengingat seorang guru harus mengajar sebanyak 24 jam per minggu, maka guru merasa kurang waktu dalam menyeleksi dan mengintegrasikan isi (content selection and integration) mata ajaran yang akan diajarkan;

2. Mengingat materi yang diajarkan (terlalu) banyak, maka masalah "proses mengkonstruksikan pengetahuan" (the knowledge construction process) yang diberikan kepada peserta didik kurang utuh, sehingga materi yang diajarkan kurang lengkap. Akibatnya proses sosialisasi yang diberikan pendidik kurang lengkap dan ini tampak pada peserta didik kurang lengkap sosialisasinya, sehingga banyak diantara anak-anak saling terjadi tawuran di masyarakat.

3. Permasalahan lain yang kurang tampak, tetapi pada sikap dan perilaku peserta didik atau orang tua murid muncul adanya prasangka yang cukup berlebihan, sehingga bagaimana pendidik atau guru dapat menguragi prasangka (prejudice reduction) tersebut? Pertanyaannya adalah: Sejauh mana guru mampu memilih aspek dan unsur budaya yang relevan dengan isi dan topik mata pelajaran?; Sejauhmana guru dapat mengintegrasikan budaya lokal dalam mata pelajaran yang diajarkan, sehingga pembelajaran lebih bermakna bagi peserta didik?; aspek budaya manakah yang dapat dipilih sehingga dapat membantu peserta didik untuk memahami konsep tepat kunci secara lebih bermakna (meaningfull learning)

4. Mengingat budaya kita sudah condong ke arah materialism, maka tolok ukur yang digunakan sering ke arah itu, sehingga bagaimana pendidik atau guru dapat mereduksi atau mengeliminasi prasangka masalah "kesetaraan pedagogy" (equity paedagogy). Contoh yang kasat mata saat ini adalah sekolahan yang mahal biayanya dengan sekolahan yang setengah gratis. Namun, masyarakat lebih tertarik kepada sekolahan mahal biayanya. Artinya, sekolahan mahal lebih disukai masyarakat daripada sekolahan yang murah. Berdasarkan hal di atas, dapat diambil kesimpulan, bahwa segala sesuatu diukur dari materi yang melekatnya.

\section{Cara Mengatasi Masalah Terhadap Peserta Didik}

Tehnik untuk mengatasi masalah yang berkaitan dengan peseta didik, atau orang tua siswa, ataudengan lembaga pendidikan,sebaiknya dipecahkansecara bersama-sama, agar proses pemecahannya lebih komprehensif dan terpadu. Mengingat proses pemecahan pendidikan, maka realisasinya seharusnya secara kooperatifdan kolaboratif dengan smooth. 
Metode ilmiah pada umumnya memuat serangkaian aktivitas pengumpulan data melalui observasi, wawancara atau ekperimen, mengolah informasi atau data, menganalisis, kemudian memformulasi, danpengujian hipotesis.

Menurut Permendikbud Nomor 81 A tahun 2013, lampiran IV menunjukkan langkah-langkah yang perlu dilakukan bersama dalam proses pembelajaran antara pendidik atau guru dengan peserta didik. Langkah-langkah pendekatan ilmiah (scientific appoach) dalam proses pembelajaran meliputi menggali informasi melalui pengamatan, bertanya, percobaan, kemudian mengolah data atau informasi, menyajikan data atau informasi, dilanjutkan dengan menganalisis, menalar, kemudian menyimpulkan, dan mencipta. Untuk mata pelajaran, materi, atau situasi tertentu, sangat mungkin pendekatan ilmiah ini tidak selalu tepat diaplikasikan secara prosedural. Pada kondisi seperti ini, tentu saja proses pembelajaran harus tetap menerapkan nilai-nilai atau sifat-sifat ilmiah dan menghindari nilai-nilai atau sifat-sifat nonilmiah. Terdapat lima unsur dalam pembelajaran kontekstual, yaitu:

\section{a. Mengamati (observasi)}

Metode mengamati mengutamakan kebermaknaan proses pembelajaran (meaningfull learning). Metode ini memiliki keunggulan tertentu, seperti menyajikan media obyek secara nyata, peserta didik senang dan tertantang, dan mudah pelaksanaannya.
Metode mengamati sangat bermanfaat bagi pemenuhan rasa ingin tahu (curiousity) peserta didik,sehingga proses pembelajaran memiliki kebermaknaan yang tinggi. Kegiatan mengamati dalam pembelajaranhendaklah guru membuka secara luas dan bervariasi kesempatan peserta didik untuk melakukan pengamatan melalui kegiatan: melihat, menyimak, mendengar, dan membaca. Guru memfasilitasi peserta didik untuk melakukan pengamatan, melatih mereka untuk memperhatikan (melihat, membaca, mendengar) hal yang penting dari suatu benda atau objek. Adapun kompetensi yang diharapkan adalah melatih kesungguhan, ketelitian, kecermatan, kepastian dan mencari informasi.

\section{b. Menanya}

Dalam kegiatan mengamati, guru membuka kesempatan secara luas kepada peserta didik untuk bertanya mengenai apa yang sudah dilihat, disimak, dibaca atau dilihat. Guru perlu membimbing peserta didik untuk dapat mengajukan pertanyaan: pertanyaan tentang hasil pengamatan objek yang konkrit sampai kepada yang abstrak berkenaan dengan fakta, konsep, prosedur, atau pun hal lain yang lebih abstrak. Pertanyaan yang bersifat faktual sampai kepada pertanyaan yang bersifat hipotetik. Berdasarkan situasi di mana peserta didik dilatih menggunakan pertanyaan dari guru, masih memerlukan bantuan guru untuk mengajukan pertanyaan sampai ke tingkat di 
mana peserta didik mampu mengajukan pertanyaan secara mandiri. Berangkat dari kegiatan tersebut dihasilkan sejumlah pertanyaan. Melalui kegiatan bertanya dikembangkan rasa ingin tahu (curiousity) peserta didik. Semakin terlatih dalam bertanya maka rasa ingin tahu semakin dapat dikembangkan. Pertanyaan tersebut menjadi dasar untuk mencari informasi yang lebih lanjut dan beragam dari sumber yang ditentukan guru sampai yang ditentukan peserta didik, dari sumber yang tunggal sampai sumber yang beragam.

Kegiatan"menanya" dalam kegiatan pembelajaran, pendidik atau guru mengajukan pertanyaan tentang informasi yang tidak dipahami dari apa yang diamati atau pertanyaan untuk mendapatkan informasi tambahan tentang apa yang diamati (dimulai dari pertanyaan faktual sampai ke pertanyaan yang bersifat hipotetik). Adapun kompetensi yang diharapkan dalam kegiatan ini adalah mengembangkan kreativitas, rasa ingin tahu, kemampuan merumuskan pertanyaan untuk membentuk pikiran kritis yang perlu untuk hidup cerdas dan belajar sepanjang hayat.

\section{c. Mengumpulkan Informasi}

Kegiatan "mengumpulkan informasi” merupakan tindak lanjut dari bertanya. Kegiatan ini dilakukan dengan menggali dan mengumpulkan informasi dari berbagai sumber melalui berbagai cara. Untuk itu peserta didik dapat membaca buku yang lebih banyak, memperhatikan fenomena atau objek yang lebih teliti, atau bahkan melakukan perlakukan (experiment). Dari kegiatan tersebut terkumpul sejumlah informasi. Dalam aktivitas mengumpulkan informasi dilakukan melalui eksperimen atau perlakuan, membaca sumber lain selain buku teks, mengamati objek/kejadian/aktivitas wawancara dengan nara sumber dan sebagainya. Adapun kompetensi yang diharapkan adalah mengembangkan sikap teliti, jujur, sopan, menghargai pendapat orang lain, kemampuan berkomunikasi, menerapkan kemampuan mengumpulkan informasi melalui berbagai cara yang dipelajari, mengembangkan kebiasaan belajar dan belajar sepanjang hayat.

\section{d. Mengasosiasikan/Mengolah}

\section{Informasi/Menalar}

Kegiatan "mengasosiasi/mengolah informasi/menalar" dalam kegiatan pembelajaran adalah memproses informasi yang sudah dikumpulkan baik terbatas dari hasil kegiatan mengumpulkan data atau eksperimen maupun hasil pengolahan informasi yang dikumpulkan dari yang bersifat menambah keluasan dasar dari kegiatan mengamati dan kegiatan mengumpulkan data/informasi. Pengolahan kedalaman sampai kepada pengolahan informasi yang bersifat mencari solusi dari berbagai sumber yang memiliki pendapat yang berbeda sampai kepada yang bertentangan. Kegiatan ini dilakukan untuk menemukan 
keterkaitan satu informasi dengan informasi lainya, menemukan pola dari keterkaitan informasi tersebut. Adapun kompetensi yang diharapkan dari kegiatan ini adalah mengembangkan sikap jujur, teliti, disiplin, taat aturan, kerja keras, kemampuan menerapkan prosedur dan kemampuan berpikir induktif serta deduktif dalam menyimpulkan.

Aktivitas ini juga diistilahkan sebagai kegiatan menalar, yaitu proses berfikir yang logis dan sistematis atas fakta-kata empiris yang dapat diobservasi untuk memperoleh simpulan berupa pengetahuan. Aktivitas menalar dalam konteks pembelajaran dengan pendekatan ilmiah banyak merujuk pada teori belajar asosiasi atau pembelajaran asosiatif. Istilah asosiasi dalam pembelajaran merujuk pada kemamuan mengelompokkan beragam ide dan mengasosiasikan beragam peristiwa untuk kemudian memasukannya menjadi penggalan memori. Selama mentransfer peristiwa-peristiwa khusus ke otak, pengalaman tersimpan dalam referensi dengan peristiwa lain. Pengalaman-pengalaman yang sudah tersimpan di memori otak berelasi dan berinteraksi dengan pengalaman sebelumnya yang sudah tersedia.

\section{e. Mengkomunikasikan}

Pada pendekatan scientific guru diharapkan memberi kesempatan kepada peserta didik untuk mengkomunikasikan apa yang telah mereka pelajari. Kegiatan ini dapat dilakukan melalui menuliskan atau menceritakan apa yang ditemukan dalam kegiatan mencari informasi, mengasosiasikan dan menemukan pola. Hasil tersebut disampikan di kelas dan dinilai oleh guru sebagai hasil belajar peserta didik atau kelompok peserta didik tersebut. Kegiatan "mengkomunikasikan" dalam kegiatan pembelajaran adalah menyampaikan hasil pengamatan, kesimpulan berdasarkan hasil analisis secara lisan, tertulis, atau media lainnya.

\section{Teknik-Teknik Mengajar di Masyrakat Multikultural}

Mengingat teknik-teknik pembelajaran multikultural rumit dan kompleks, maka proses pembelajarannya haruslah bersifat kolaburatif dan kontekstual. Mengapa demikian? Masyarakat multikultural yang peserta didiknya yang beragam, baik dilihat budaya, etnis, agama, dan stratifikasinya. Keragamannya masyarakat multikulturalnya diharapkan guru menyampaikan contohcontoh isi mata ajaran tidak menimbulkan prasangka (prejudice reduction) dalam proses pembelajaran.

Model pembelajaran adalah bentuk pembelajaran yang tergambar dari awal sampai akhir yang disajikan secara khas oleh pendidik atau guru. Model pembelajaran merupakan bingkai dari penerapan suatu pendekatan, metode, dan teknik pembelajaran. Ada banyak model pembelajaran dan beberapa 
yang disarankan di dalam pelaksanaan pembelajaran saintifik, diantaranya adalah:

\section{Inquiry Based Learning}

Langkah-langkah atau sintaks Inquiry Based Learning, secara umum dalam proses pembelajaran adalah sebagai berikut:

a. Observasi/Mengamati

b. Mengajukan pertanyaan

c. Mengajukan dugaan atau kemungkinan jawaban/ mengasosiasi atau melakukan penalaran

d. Mengumpulkan data yang terakait dengan dugaan atau pertanyaan yang diajukan/memprediksi dugaan

e. Merumuskan kesimpulan-kesimpulan berdasarkan data yang telah diolah atau dianalisis, dan dipresentasikan

\section{Discovery Based Learning}

Langkah-langkah atau sintaks Discovery Based Learning dalam pembelajaran adalah sebagai berikut:

a. Stimulation (memberi stimulus), baik berupa bacaan, gambar atau situasi yang sesuai dengan materi atau bahan pembelajaran atau sesuai dengan tema atau topik materi pembelajaran;

b. Problem Statement (mengidentifikasi masalah) dalam kegiatan ini adalah menemukan permasalahan menanya, mencari informasi dan merumuskan masalah.

c. Data Collecting (mengumpulkan data)adalah kegiatan dalam mencari dan mengumpulkan data atau informasi, termasuk dalam melatih nomerator/peneliti tentang proses pengumpulan data seperti ketelitian, akurasi dan kejujuran dalam mencari atau merumuskan berbagai alternatif pemecahan masalah

d. Data Processing (mengolah data) adalah kegiatan dalam mencoba dan mengeksplorasi pengetahuan konseptual, melatih keterampilan berpikif logis dan aplikasinya.

e. Verfication (memferikasi) adalah kegiatan dalam mengecek kebenaran atau keabsahan data, pengolahan data, mencari sumber yang relevan yang baik dari relevan buku atau media dan mengasosiasikannya untuk menjadi suatu kesimpulan secara utuh.

f. Generalization (menyimpulkan dari hasil penelitian agar dapat melatih pengetahuan metakognisi pada peserta didik.

\section{Problem Based Learning}

Langkah-langkah atau sintaks

Problem Based Learning, secara umum dalam pembelajaran adalah sebagai berikut:

a. Orientasi pada masalah dengan mengamati masalah yang menjadi objek pembelajaran

b. Pengorganisasian kegiatan pembelajaran dengan menyampaikan berbagai pertanyaan (atau menanya) terhadap masalah kajian 
c. Penyelidikan mandiri dan kelompok dan melakukan percobaan (mencoba) untuk memperoleh data dalam rangka menyelesaikan masalah yang dikaji.

d. Pengembangan dan pengkaian hasil, dan mengasosiasikan data yangditemukan dengan berbagai data lain dari berbagai sumber, dan

e. Analisis dan evaluasi proses pemecahan masalah.

\section{Project Based Learning}

Langkah-langkah atau sintaks Project Based Learning, secara umum dalam pembelajaran adalah sebagai berikut:

a. Menyiapkan pertanyaan atau penugasan proyek, sejak langkah awal agar peserta didik mengamati lebih detail atau dalam terhadap pertanyaan yang muncul dari fenomena yang ada.

b. Merancang atau mendesain perencanaan proyek, mulai menyusun perencanaan proyek atau bisa juga dengan perencanaan percobaan (rancob);

c. Menyusun jadual sebagai pedoman atau arahan dalam melaksanakan langkahlangkah nyata dari sebuah projek tersebut;

d. Memonitor kegiatan dan perkembangan projek, serta mengevaluasi projek yang sedang dikerjakan atau sedang berjalan;

e. Menguji hasil yang diperoleh, baik berupa fakta dan data yang dihubungkan dengan berbagai data lain;

f. Mengevaluasi kegiatan atau pengalaman yang diperoleh sebagai acuan perbaikan untuk perbaikan tugas projek pada mata ajaran yang sama atau mata ajaran lain pada waktu yang akan datang.

Berangkat dari 4 (empat) klasifikasi pembelajaran konteksual yang bersifat kerjasama dan kolaburatif ini dalam pelaksanaan praktis dan nyata dapat dilakukan dengan, antara lain: diskusi atau FGD (focus group discussion), melakukan perlakuan (experiment) atau rancangan percobaan, demonstrasi dan atau simulasi. Dalam pelaksanaannya lebih operasonal dan praktis, seperti adanya penyampaian informasi, dan jenis pelaksanaannya bersifatpenugasan, dsb. Kesemuanya itu, tergantung pada materi yang diajarkan dan metode yang digunakan untuk mencapai tujuan pembelajaran--yang sesuai dengan karakteristik peserta didik.

\section{E. Penutup}

Berdasarkan uraian di atas, dapat diambil beberapa kesimpulan, antara lain:

1. Problematika Pendidik Sosiologi dan Antropologi sangat komplek, sejak pendidk atau guru yang kurang profesional, sampai dengan menghadapi peserta didik yang multikultural, baik etnis, budaya, ras, agama dan golongan.

2. Problema yang dihadapi pendidik atau guru semakin kompleks, sejak dari orientasi peserta didik dengan tuntutan penyetaraan pelayanan dalam menyeleksi dan mengintegrasikan isi (content selection and integration); masalah 
"proses mengkonstruksikan pengetahuan" (the knowledge construction process); menguragi prasangka (prejudice reduction)? Masalah adalah: Sejauh mana guru mampu memilih aspek dan unsur budaya yang relevan dengan isi dan topik mata pelajaran, sehingga peserta didik menuntut penyetaraan pendididkan (equity of education).

3. Dengan problema pendidik yang kompleks tersebut, stakehodler (pemangku kepentingan) menuntut pelayanan pendidikan atau pembelajaran yang aktif, kreatif, efektif danmenyenangkandalam pembelajaran secara kontekstual dengan pendekatan saintifik.

4. Dengan pendekatan saintifik, proses kerja pemecahan masalah dalam pendidikan harus memenuhi kriteria ilmiah (scientefict methods), dengan lebih mengedepankan pelararan induktif (inductive reasoning) dibandingkan dengan penalaran deduktif (deductive reasoning). Penalaran deduktif melihat fenomena umum untuk kemudian ditarik simpulan yang spesifik. Sebaliknya, penalaran induktif memandang fenomena atau situasi spesifik untuk kemudian ditarik simpulan secara keseluruhan. Intinya, penalaran induktif menempatkan bukti-bukti spesifik ke dalam relasi ide yang lebih luas dengan metode pencarian (method of inquiry) berbasis pada buktibukti dari objek yang dapat diobservasi, empiris, dan terukur dengan prinsipprinsip penalaran yang spesifik.

5. Problem pendidik atau guru di masyarakat multikultural yang demikian, di samping dengan pendekatan saintifik (5M, yaitu: mengamati, menanya, mengumpulkan informasi, mengasosiasi atau menalar dan mengkomunikasikan hasilnya), juga dengan model pembelajaran yang kolaburatif dan konekstual dengan: Inquiry Based Learning; Discovery Based Learning; Problem Based Learning; dan Project Based Learningdegan pelakanaan praktis dan nyata atara dengan diskusi atau FGD (focus group discussion), melakukan perlakuan (experiment) atau rancangan percobaan, demonstrasi dan atau simulasi. 


\section{DAFTAR REFERENSI}

Achmad Fedyani Saifuddin. 1986. Konflik dan Integrasi: Perbedaan Faham dalam Agama Islam. Jakarta: Rajawali.

Chairol Mahfud. 2008. Pendidikan Multikultural. Yogyakata Pustaka Pelajar

Joyce, dkk. 2009. Models of Teaching.Yogyakarta:Pustaka Pelajar.

Permendikbud Nomor 81A Tahun 2013 lampiran IV Pedoman Umum Pembelajaran. Jakarta: Kemendikbud.

Tim pengembang, 2014. Materi Pelatihan Guru Implementasi Kurikulum 2013 Tahun 2014. Jakarta: Kemendikbud.

Tilaar, HAR, 2003. Kekuasaan dan Pendidikan; suatu Tinjauan dari perspektif studi kultural, Bandung: Remaja Rosdakarya

Trianto. 2007. Model-Model Pembelajaran Inovatif Berorientasi Konstruktivistik: Konsep, Landasan Teoritis-Praktis dan Implementasinya. Jakarta: Prestasi Pustaka.

Zaini Rohmad, 2015. Sosiologi Pembangunan. Yogyakarta: CV. Ombak 2016. Asesmen dan Evaluasi Pembelajaran. Surakarta: UNS Press. 2017. Pendidikan Orang Dewasa. Surakarta: LPPM UNS Press 